\title{
FUNDAMENTAL OBJECTIONS TO THE WALSH BILL
}

\author{
BY FREDERICK LAW OLMSTED
}

\begin{abstract}
The Walsh bill permits the Yellowstone river to be dammed three miles below Lake Yellowstone in favor of private interests. It is a menace to Yellowstone park, as will appear from the following statement made before the Senate Committee on Irrigation. ::
\end{abstract}

1. Thrs bill would definitely and irrevocably withdraw not merely from the agency which congress has set up for the administration of the national parks, but absolutely and finally from all agencies of the federal government, the power of decision and the right of delegating the power of decision, innumerable matters of design, construction, maintenance and operation intimately affecting Yellowstone Lake, which is the central feature of the Yellowstone national park, and would transfer these powers, through the state of Montana, to an agency or agencies whose purpose and whose positive duty would be not primarily the conservation and enhancement of the values of the park for the people of the United States, but the protection and enhancement of certain local property values and other local interest at the lowest practicable cost to the people immediately concerned.

2. Where it is possible and advisable in the management and operation of property for any given purpose to secure incidental values, or by-products, through serving also some secondary purpose, it is essential to businesslike administration that the final power of practical control over the operations which are directed to securing that byproduct must remain with those who are responsible for securing the principal values. Otherwise the by-product is liable to be secured at an excessive sacrifice of the principal values.

For example: The principal business of public schools is education; although it is often practicable and desirable to use public school buildings for other purposes in addition, such as public meetings. Yet it would be manifest folly to divest the board of education permanently of the power of determining when and how public meetings are to be held in the school buildings and to place it in the power of some other body to settle such matters when their opinion differs from that of the board of education.

3. These considerations apply with peculiar force to parks, because the precise manner and conditions of their most effective service to the public, and the precise effect of any physical operations upon the quality of their natural landscape and upon their general value are very difficult to determine with precision in advance; and especially because the result of any given methods of operation and management is cumulative over many years of growth and betterment, or of gradual deterioration, and often the effect is not generally appreciated until the causes have been at work for a long time. $I_{t}$ is one of the most important functions of a park administration to be watchfully alert to such cumulative effects and tendencies of the methods employed and uses 
permitted and to correct the inevitable mistakes of judgment as far as practicable before their injurious effects become excessive.

4. This bill and other propositions to use national parks for incidental or secondary purposes which are entirely distinct from those for which the parks were created-propositions to secure valuable by-products of an economic sort from the parks while maintaining them for their principal purposes-are ostensibly predicated on the assumption that these by-products can be secured without impairment of the value of the parks as parks.

I cannot too strongly emphasize the lesson which I have learned from years of experience with park administration all over the country, that the only safe way in which to obtain any such byproducts without material and often fatal sacrifice of the prime park values is to place the responsibility for, and effective permanent control over, all the details in the hands of those whose duty and purpose it is to protect these prime values.

A thorough and impartial investigation might establish or might disprove the practicability of so regulating the outflow of Yellowstone lake as to secure material economic benefits without injury to the value of the park for its proper purpose. But if this possibility should be clearly established, I am positive that the only safe way to attempt its realization would be to place the complete and undivided responsibility for all the work upon the same agency which is made responsible for maintaining the park values as a whole; to the end that this economic by-product should be secured just in so far as it is compatible with the prime purpose of the park, and no farther.

Any other method is equivalent to a city's giving to a convention bureau the right and duty of determining when and how it will use a high school auditorium regardless of the opinion of the board of education.

5. If you ask me for a specific opinion on the general proposition of regulating the outflow of Yellowstone lake, aside from the fundamentally mistaken method of accomplishing that result which is proposed in the present bill, I can only say that $I$ have not yet had opportunity to study it with sufficient thoroughness to venture a positive professional opinion.

A dam of the sort indicated in the prospectus now before your committee, operated under the conditions laid down in that prospectus, would be certain to injure the park appreciably; and if operated with first regard for the interests of its local beneficiaries rather than for the interests of the users of the park, as would be the inevitable result of alienating its management and control from the United States, would be likely to work a surprising amount of injury.

Whether a dam and regulating gates suitably designed and suitably operated with an appreciative and skillful understanding of park requirements could accomplish, without appreciable net injury to the park, economic results worth more than the cost of construction, maintenance and operation, I am not prepared to say without a thorough study of the conditions.

But I would no more think of alienating the right to construct and operate such regulating devices to local interests, than an irrigation district whose object is to draw upon its reservoir for the maximum supply of water during two or three months would freely and irrevocably entrust the operation of its reservoir to a power company whose object is to secure a steady flow of water throughout the entire year. 